\title{
Water Potential and Its Components in Developing Sweet Cherry
}

\author{
Christine Schumann, Henrik Jürgen Schlegel, Eckhard Grimm, and Moritz Knoche ${ }^{\mathbf{1}}$ \\ Institute for Horticultural Production Systems, Fruit Science Section, Leibniz University Hannover, \\ Herrenhäuser Straße 2, 30419 Hannover, Germany
}

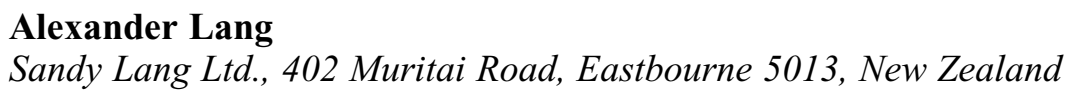

AdDitional INDEX wORDs. cuticular membrane, flesh, osmotic potential, pressure, Prunus avium, skin, turgor

Abstract. Susceptibility of sweet cherry (Prunus avium L.) fruit to rain cracking increases toward maturity and is thought to be related to increases in both tissue pressure $\left(\Psi_{P}^{\text {fruit }}\right)$ and cell pressure $\left(\Psi_{P}^{\text {cell }}\right)$. Furthermore, at a given water potential $\left(\Psi^{\text {fruit }}\right)$, one might expect the increase in $\Psi_{P}^{\text {fruit }}$ and the $\Psi_{P}^{\text {cell }}$ to balance the decrease in osmotic potential $\left(\Psi_{\Pi}^{\text {fruit }}\right)$. The objectives of our study were to quantify $\Psi_{P}^{\text {fruit }}$ and $\Psi_{P}^{\text {cell }}$ in developing sweet cherry using vapor pressure osmometry (VPO), compression plate (CP), and the cell pressure probe (CPP). In addition, the tissue water potential $\Psi^{\text {tissue }}$ was determined by quantifying the bending of strips of fruit skin and the change in projected area of discs excised from the flesh when incubated in a range of sucrose solutions of varying osmotic potentials $\left(\Psi_{\Pi}^{\text {solution }}\right)$. Fruit growth followed a sigmoid pattern with time with the Stage II/Stage III transition occurring at $\approx \mathbf{5 5}$ days after full bloom (DAFB). The $\Psi^{\text {tissue }}$ and the $\Psi_{\Pi_{\text {fruit }}}^{\text {fruit }}$ were constant up to $\approx 55 \mathrm{DAFB}$ but decreased to $-2.8 \mathrm{MPa}$ at maturity. The $\Psi_{P}^{\text {cell }}$ calculated by subtracting the $\Psi_{\Pi}^{\text {fruit }}$ from $\Psi^{\text {tissue }}$ averaged $\approx 350 \mathrm{kPa}$ up to $48 \mathrm{DAFB}$ and then decreased at a decreasing rate to $\approx 21 \mathrm{kPa}$ toward maturity. The $\Psi^{\text {tissue }}$ determined from bending assays using excised skin strips or from water uptake of excised flesh discs was essentially constant up to $\approx 48$ DAFB, then decreased until $\approx 75$ DAFB and remained constant thereafter. These $\Psi^{\text {tissue }}$ values were in good agreement with those determined by VPO. The $\Psi_{P}^{\text {fruit }}$ as determined by CP passed through a transient peak at $\approx 41$ DAFB, then decreased until $\approx 63$ DAFB and remained constant and low until maturity. Similarly, $\Psi_{P}^{\text {cell }}$ by CPP increased from 27 to 48 DAFB, remained constant until $\approx 55$ DAFB, and then decreased until maturity. Our data demonstrate a consistent decrease in $\Psi_{P}^{\text {fruit }}$ and $\Psi_{P}^{\text {cell }}$ that coincides with a decrease in $\Psi_{\Pi}^{\text {fruit }}$ of sweet cherry during Stage III. Because $\Psi_{P}^{\text {fruit }}$ and $\Psi_{P}^{\text {cell }}$ are low relative to $\Psi_{\Pi}^{\text {fruit }}{\text {, the change in } \Psi^{\text {fruit }} \text { parallels that }}^{\text {frit }}$ in $\Psi_{\Pi}^{\text {fruit }}$. The reason for the low turgor most likely lies in the accumulation of apoplastic solutes. These prevent a catastrophic increase in pressure that would otherwise lead to the bursting of individual cells and the cracking of entire fruit.

Many soft and fleshy fruit crack on exposure of the fruit to surface water. Osmotic water uptake that occurs along a gradient in water potential between the surface water on the fruit and the water inside the fruit is thought to be causal. The water potential of the fruit $\Psi$ fruit comprises two major components, an $\Psi_{\Pi}^{\text {fruit }}$ caused by the presence of significant concentrations of carbohydrates. The second component is the tissue pressure inside the fruit $\left(\Psi_{P}^{\text {fruit }}\right)$ that results from the strained and stressed fruit skin that holds the flesh under pressure in analogy with the turgor of an individual cell $\left(\Psi_{P}^{\text {cell }}\right)$ generated by the strained and stressed cell wall. Thus, the $\Psi_{\Pi}^{\text {fruit }}$ stimulates ingress of water, whereas the pressures $\Psi_{P}^{\text {fruit }}$ and $\Psi_{P}^{\text {cell }}$ work in opposition to one another and tend to limit the ingress of water. The $\Psi_{\Pi}^{\text {fruit }}$ of expressed juices of soft and fleshy fruit are very low (highly negative) and for mature (sweet) cherry and grape (Vitis vinifera L.), values of $\Psi_{\Pi}^{\text {frut }}$ as low as $-5 \mathrm{MPa}$ have been reported (Tyerman et al., 2004).

For a cherry grown under irrigated conditions and examined just before dawn, one might anticipate near-equilibrium water potential conditions within the fruit and so fruit $\left(\Psi^{\text {fruit }}\right)$ and cell

Received for publication 2 Mar. 2014. Accepted for publication 10 Apr. 2014. This research was funded in part by a grant from the Deutsche Forschungsgemeinschaft.

We thank Friederike Schroeder and Simon Sitzenstock for technical assistance and Drs. Fritz Lenz and Bishnu P. Khanal for helpful comments on an earlier version of this manuscript.

${ }^{1}$ Corresponding author. E-mail: moritz.knoche@obst.uni-hannover.de.
$\left(\Psi^{\text {cell }}\right)$ water potentials that are close both to one another and also to zero (i.e., $\Psi^{\text {fruit }} \approx \Psi^{\text {cell }} \approx 0$ ). This assumption is based on the following arguments. First, the fruit surface is covered by a cuticle that represents the dominant rate-limiting barrier to transpiration. Thus, internal resistors to water transfer such as the plasma membranes should not be a significant factor. Their permeability is usually around three orders of magnitude larger than that of the cuticle. Second, transpiration at night is low (air humidity is usually high so driving force is usually low) and therefore, we would expect any gradient in water potential (that is unlikely to be present in the first place) to have disappeared as a result of equilibration. Third, we are not aware of any published data reporting an internal water potential gradient within a fruit. Under the conditions described, the rapid decreases in $\Psi_{\Pi}^{\text {fruit }}$ as maturity is approached (Knoche et al., 2004) might be expected to be balanced by corresponding rapid increases in tissue pressure $\left(\Psi_{P}^{\text {friti }}\right)$ and cell pressure $\left(\Psi_{P}^{\text {cell }}\right)$. We note that the concept of tissue pressure is analogous to that of the cell pressure (or turgor) of an individual cell but refers to the whole fruit (occasionally $\Psi_{P}^{\text {fruit }}$ is also referred to as fruit turgor). Consistent with these hypothetical increases in $\Psi_{P}^{\text {fruit }}$ and $\Psi_{P}^{\text {cell }}$ would be an increase in the fruit's susceptibility to cracking, which fits with the idea that its susceptibility is related to increased tissue pressure caused by water uptake (Measham et al., 2009; Sekse, 1995; Sekse et al., 2005). Based on this understanding, water uptake increases fruit volume and, hence, fruit surface area. The fruit skin, being thus strained, accumulates increasing levels of stress, which generates a tissue 
pressure $\Psi_{P}^{\text {fruit }}$. Failure of the skin is expected to occur when its limit of extensibility is exceeded. The hypothetical tissue pressure threshold at which skin failure and cracking occurs is referred to as the critical tissue pressure (turgor) (Considine and Kriedemann, 1972; Measham et al., 2009). According to the critical tissue pressure concept, one would expect $\Psi_{P}^{\text {fruit }}$ in a cherry to increase through the final stages of development [Stage III, "final swell" (Lilleland and Newsome, 1934; Tukey, 1934)] when the cracking susceptibility also increases (Christensen, 1996).

Both lines of arguments imply that we should expect to record increases in $\Psi_{P}^{\text {fruit }}$ and $\Psi_{P}^{\text {cell }}$ during Stage III of development.

Although this logic would seem to offer a satisfactory conceptual framework within which to understand fruit cracking, recent measurements of $\Psi_{P}^{\text {fruit }}$ and $\Psi_{P}^{\text {cell }}$ in mature cherry indicate: 1) that $\Psi_{P}^{\text {fruit }}$ and $\Psi_{P}^{\text {cell }}$ do not have high values but, instead, have values very close to zero (i.e., atmospheric pressure) (Knoche et al., 2014). Furthermore, 2) laboratory manipulations of fruit water status (e.g., by permitting isolated fruit to take up water by osmosis from a bathing solution or to lose water by transpiration to dry air) have essentially no effect at all on $\Psi_{P}^{\text {fruit }}$ (Knoche et al., 2014). Thus, we infer that this conceptual framework may not be as useful as would first appear.

To provide a more useful understanding of fruit water relations in cherry, $\Psi_{P}^{\text {fruit }}$ and $\Psi_{P}^{\text {cell }}$ were quantified in developing fruit using a vapor pressure osmometer, a compression plate, and a cell pressure probe. The value $\Psi^{\text {fruit }}$ was also determined by following changes in the curvatures of strips of fruit skin (with a layer of adhering flesh) and changes in the projected surface areas of excised flesh discs when incubated in sucrose solutions of a range of osmotic potentials. The study focused on Stage III of fruit development because this is the period characterized by particularly rapid changes in cracking susceptibility and it is also when $\Psi_{\Pi}^{\text {fruit }}$, measured on expressed juice samples, suffers its most marked decrease (increase in negativity).

\section{Materials and Methods}

Plant material. Developing fruit of the 'Regina' sweet cherry of uniform size and color were sampled at regular intervals from greenhouse-grown trees grafted on 'Gisela 5' rootstocks (Prunus cerasus L. $\times$ Prunus canescens Bois) at the Horticultural Research Station of the Leibniz University Hannover at Sarstedt/Ruthe, Germany (lat. $52^{\circ} 14^{\prime} \mathrm{N}$, long. $9^{\circ} 49^{\prime} \mathrm{E}$ ). Unless otherwise specified, fruit was processed on the day of sampling. Fruit mass was determined $[n=20$ (CPA 225D and BP 211D; Sartorius, Göttingen, Germany)] and fruit color quantified in the CIE $1976\left(\mathrm{~L}^{*}, \mathrm{a}^{*}, \mathrm{~b}^{*}\right)$ scale as defined by the Commission Internationale de l'É-clariage (McGuire, 1992) using a chromometer (CR-200; Minolta, Osaka, Japan). To describe the change in color of the developing fruit, the hue angle was calculated as described by McGuire (1992). Three readings were taken per fruit on a total of 20 fruit per sampling date.

Measuring $\Psi^{\text {tissue }}, \Psi_{\Pi}^{\text {fruit }}$, AND $\Psi_{P}^{\text {cell }}$ USING VPO. Values of $\Psi^{\text {tissue }}, \Psi_{\Pi}^{\text {fruit }}$, and $\Psi_{P}^{\text {cell }}$ of the flesh of developing 'Regina' sweet cherry were measured using a vapor pressure osmometer $\left(\right.$ VAPRO $^{\circledR}$ 5520; Wescor, Logan, UT). Briefly, a skin + flesh disc ( $8 \mathrm{~mm}$ diameter) was excised from the cheek of a visually perfect fruit and the adhering flesh trimmed to $2 \mathrm{~mm}$ thickness. The sample was blotted gently using soft tissue paper (7216; Kimberly-Clark, Reigate, U.K.) and, within $60 \mathrm{~s}$ of excision, was placed in the sample holder $(9.5 \mathrm{~mm}$ diameter, $4.5 \mathrm{~mm}$ depth) of the osmometer. The value of the tissue water potential
( $\Psi^{\text {tissue }}$ ) was read at stability, 15 min after closure of the sample chamber. Preliminary studies established that this interval was sufficient to establish an equilibrium reading (Knoche et al., 2014). Next, the sample chamber was opened, the tissue disc was thoroughly crushed in the sample holder using a cylindrical glass rod (matching diameter of $9.5 \mathrm{~mm}$ ), the chamber again closed, and a second value for $\Psi^{\text {tissue }}$ was recorded after a further 15-min equilibration time. This second reading is assumed to represent an evaluation of $\Psi_{\Pi}^{\text {fruit }}$ of the same sample (the cells having been destroyed by crushing, any contribution to tissue water potential from cell pressure is reasonably assumed to be negligible). Where $\Psi^{\text {tissue }}=\Psi_{P}^{\text {cell }}+\Psi_{\Pi}^{\text {fruit }}$, a value for $\Psi_{P}^{\text {cell }}$ was calculated by subtracting $\Psi_{\Pi}^{\text {fruit }}$ from $\Psi^{\text {tissue }}$. This procedure allows establishment of values of $\Psi^{\text {tissue }}, \Psi_{\Pi}^{\text {fruit }}$, and $\Psi_{P}^{\text {cell }}$ for individual fruit. Determinations were carried out on 10 replicate fruit.

MeASURING $\Psi^{\text {tissue }}$ USING WATER UPTAKE AND BENDING ASSAYS. Tissue water potential $\Psi^{\text {tissue }}$ was determined using two assays: a water uptake assay and a bending assay.

For the water uptake assay, flesh discs $(8 \mathrm{~mm}$ diameter, $2 \mathrm{~mm}$ high) were excised as described previously and incubated at $22{ }^{\circ} \mathrm{C}$ for $2 \mathrm{~h}$ in a series of aqueous sucrose solutions having concentrations ranging from 0 to $1.5 \mathrm{M}$ (equivalent to 0 to 3.6 $\mathrm{MPa}$ at $22^{\circ} \mathrm{C}$ ). Control discs were incubated in silicone oil (AK 10; Wacker Chemie, Munich, Germany) to minimize water gain/loss. Except for the first sampling date, all tissue discs comprised flesh only. Discs were photographed within 5 min of the start of incubation and then again $2 \mathrm{~h}$ later using a digital camera (Altra 20; Olympus Europa, Hamburg, Germany). The cross-sectional areas $[A$ (square millimeters) $]$ of the discs were quantified by image analysis (cell $\mathrm{p}$; Olympus Europa) at $0 \mathrm{~h}$ $\left(A_{0 \mathrm{~h}}\right)$ and at $2 \mathrm{~h}\left(A_{2 \mathrm{~h}}\right)$ and the changes in area [ $\Delta A$ (square millimeters)] calculated by the difference. The 2-h interval was chosen after a preliminary study, which established that this was sufficient to allow significant $\Delta A$ values to be recorded (C. Schumann, unpublished data). The $\Psi^{\text {tissue }}$ was determined by linear regression of $\Delta A$ vs. the $\Psi_{\Pi}^{\text {solution }}$ of the incubation solution. The value $\Psi^{\text {tissue }}$ corresponded to the $\Psi_{\Pi}^{\text {solution }}$ value (by interpolation) where $\Delta A$ was the same as that recorded for discs incubated in silicone oil. For more mature fruit, in less concentrated solutions, some cells burst as a result of excessive water uptake; the regression was therefore restricted to pairs of values over narrow ranges of concentration $(0.25$ to $1.5 \mathrm{M}$ for fruit $48 \mathrm{DAFB}$ and 1.0 to $1.5 \mathrm{M}$ for fruit $55 \mathrm{DAFB}$ or later). Only during early fruit development (27 to 41 DAFB) was the full concentration range ( 0 to $1.5 \mathrm{M}$ sucrose) able to be used in the regression. Bursting of cells was indicated by high variability of the $\Delta A$ value and for more mature fruit by the discoloration of the incubation solution resulting from leakage of vacuolar anthocyanins. The number of replications was 10 .

For the bending assay, skin strips comprising cuticle, epidermis, hypodermis, and adhering flesh were prepared using parallel razorblades. Strips were excised from the cheek of the fruit parallel to the pedicel/stylar-scar axis. Strips were $2 \mathrm{~mm}$ wide, $2 \mathrm{~mm}$ high, and $10 \mathrm{~mm}$ long for fruit from 27 to $55 \mathrm{DAFB}$ and $17 \mathrm{~mm}$ long for fruit from 62 to 97 DAFB. Strips were incubated at $22{ }^{\circ} \mathrm{C}$ for $2 \mathrm{~h}$ in aqueous sucrose solutions of a series of concentrations from 0 to $1.5 \mathrm{M}$ or in silicone oil (control). Strips were photographed within $5 \mathrm{~min}$ of incubation and again after $2 \mathrm{~h}$. The angle of curvature [ $C$ (degrees)] was quantified by image analysis (cell $\wedge$; Olympus Europa) at $0 \mathrm{~h}$ $\left(C_{0 \mathrm{~h}}\right)$ and at $2 \mathrm{~h}\left(C_{2 \mathrm{~h}}\right)$. The change in curvature $(\Delta C)$ was calculated by subtracting $C_{2 \mathrm{~h}}$ from $C_{0 \mathrm{~h}}$. The $\Psi^{\text {tissue }}$ in the 
bending assay was calculated as described previously for the water uptake assay. The number of replications was 10 .

QuANTIFYING $\Psi_{P}^{\text {fruit }}$ BY CP. Values of $\Psi_{P}^{\text {fruit }}$ were measured using the CP test as described for grapes by Bernstein and Lustig $(1981,1985)$ and adapted for sweet cherry by Knoche et al. (2014). Briefly, a fruit was positioned between the two parallel plates of a universal material testing machine $(Z 0.5$; Zwick Roell, Ulm, Germany) equipped with a 500-N force transducer (KAF-TC; Zwick Roell). The lower compression plate was manufactured from translucent, etched glass such that the aplanation area between the cheek of the fruit and the glass plate could be photographed through it with a digital camera (Altra 20; Olympus Europa) and later quantified by image analysis (cell ^p; Olympus Europa). For contrast enhancement the fruit surface was covered with a thin coat of silicone grease. Before initiation of the test, the compression plate was brought into contact with the fruit by applying a force of $0.05 \mathrm{~N}$. Subsequently, the force was increased stepwise to $2 \mathrm{~N}$, in $0.25-\mathrm{N}$ increments, the position of the plates was held constant for $20 \mathrm{~min}$ at any one step, and the aplanation area quantified. Earlier studies established that within $20 \mathrm{~min}$ of a deformation, the fruit shape had reached an approximate asymptote and the aplanation area remained constant (Knoche et al., 2014). The value of $\Psi_{P}^{\text {fruit }}$ (megapascals) was calculated as the slope of a linear regression of force $[F$ (Newtons) $]$ vs. aplanation area. The number of replications was five.

Determining $\Psi_{P}^{\text {cell }}$ using THE CPP. A CPP as described by Steudle (1993) was used to measure the pressure of parenchyma cells of the outer flesh in the cheek region $\approx 200$ to $400 \mu \mathrm{m}$ below the epidermal surface. The CPP comprised a glass capillary (tip diameter 30 to $60 \mu \mathrm{m}$ ) filled with silicone oil (AS 4; Wacker Chemie, Munich, Germany) and connected to a pressure transducer (26PCGFA6D; Honeywell Sensing and Control, Golden Valley, MN). The CPP was mounted on the motorized stage of a micromanipulator positioned on a damping table. The capillary of the CPP was carefully inserted into the fruit under a horizontal microscope. Following volume correction, the peak pressure of the system was recorded and the apparatus subsequently checked for plugging and leakage artefacts as described previously (Knoche et al., 2014). As described earlier, there was no significant difference $(P=0.55$, paired observation $t$ test) in $\Psi_{P}^{\text {cell }}$ between peak pressure recorded following the pushback for volume correction $[234 \pm 40 \mathrm{kPa}(\mathrm{n}=$ 10)] and the pressure when the oil:water meniscus was held immediately above the fruit surface $[273 \pm 30 \mathrm{kPa}(\mathrm{n}=10)$; E. Grimm, unpublished data)]. For a more detailed description including a representative time course of pressure during a typical insertion, the reader is referred to Knoche et al. (2014). Analyses of pressure traces were restricted to insertions where 1) the seal between capillary and cell remained leak-free when subjecting cells to small, transient increases in pressure; and 2) the pressure returned to an ambient value after the capillary had been withdrawn from the fruit. If these conditions were met, the peak pressure recorded in the oil was taken as an estimate of the $\Psi_{P}^{\text {cell }}$.

DAta ANALyses. Data were subjected to linear and non-linear regression using Proc REG and Proc NLIN (SAS Version 9.1.3; SAS Institute, Cary, NC).

\section{Results}

FRUIT MASS AND COLOR. Fruit mass increased between 27 and 97 DAFB following a sigmoid pattern (Fig. 1A). The transition from Stage II to Stage III development occurred at $\approx 55$ DAFB when fruit color began to change from green to yellow and later to red as indicated by the decrease in hue angle (Fig. 1B). The maximum rate of growth averaged $0.28 \mathrm{~g} \cdot \mathrm{d}^{-1}$ at 66 DAFB and happened to coincide with the maximum rate of change in color.

QUANTIFYING $\Psi^{\text {tissue }}, \Psi_{\Pi}^{\text {fruit }}$, AND $\Psi_{P}^{\text {cell }}$ BY VPO. The $\Psi^{\text {tissue }}$ and the $\Psi_{\Pi}^{\text {fruit }}$ were constant up to $\approx 55$ DAFB but decreased thereafter and remained at low levels until maturity (Fig. 2A).

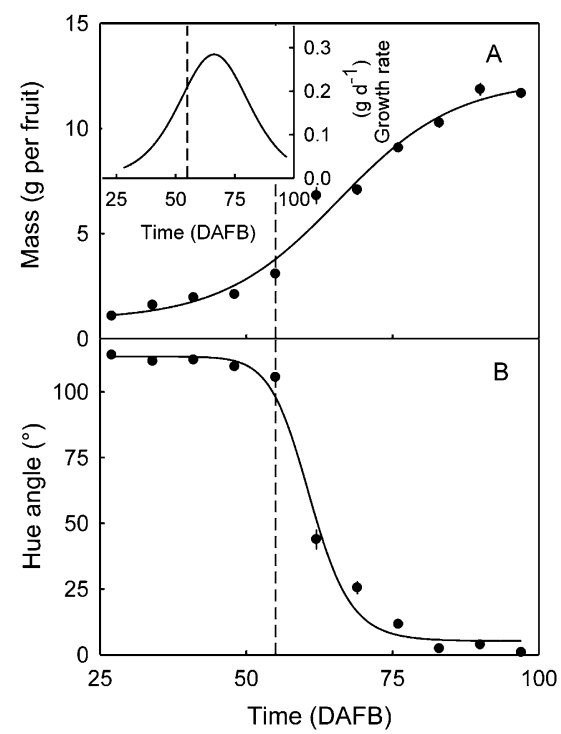

Fig. 1. Time course of change in mass, growth rate (inset $\mathbf{A}$ ) and color of developing 'Regina' sweet cherry (B). Color was indexed by the hue angles that between $100^{\circ}$ and $115^{\circ}$ represent green and between $0^{\circ}$ and $10^{\circ}$ represent red. The vertical dashed line indicates the transition from Stage II to Stage III at $\approx 55 \mathrm{~d}$ after full bloom (DAFB).

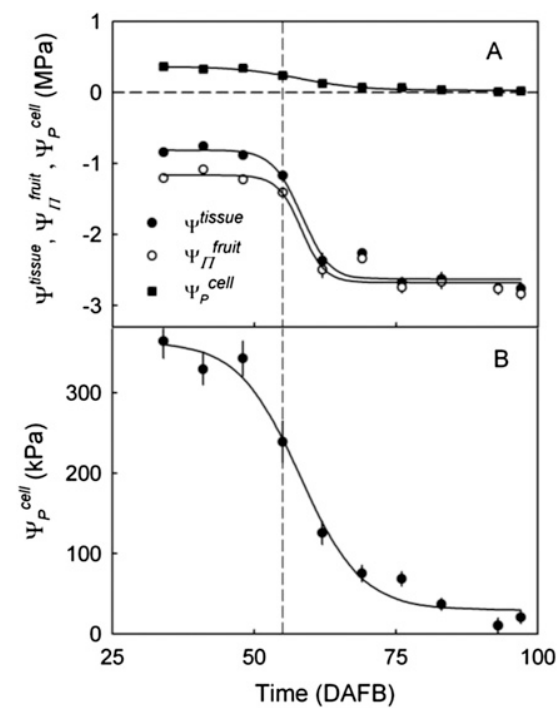

Fig. 2. (A) Time course of change in water potential of excised flesh discs $\left(\Psi^{\text {tissue }}\right)$, their osmotic potential $\left(\Psi_{\Pi}^{\text {fruit }}\right)$, and the calculated cell pressure $\left(\Psi_{P}^{\text {cell }}\right)$ of the flesh of developing 'Regina' sweet cherry; (B) $\Psi_{P}^{\text {cell }}$ as in A but redrawn on a different scale. The $\Psi_{P}^{\text {cell }}$ was calculated from $\Psi_{P}^{\text {cell }}=\Psi^{\text {tissue }}$ $\Psi_{\Pi}^{\text {fruit }}$. The vertical dashed lines indicate transition from Stage II to Stage III at $\approx 55 \mathrm{~d}$ after full bloom (DAFB). 
An estimate of the $\Psi_{P}^{\text {cell }}$ was obtained from the difference $\Psi^{\text {tissue }}-\Psi_{\Pi}^{\text {fruit }}$. The $\Psi_{P}^{\text {cell }}$ value was stable at $\approx 350 \mathrm{kPa}$ until $\approx 48$ DAFB but then decreased asymptotically toward maturity at which stage it averaged $\approx 21 \mathrm{kPa}$ (Fig. $2 \mathrm{~B}$ ).

QuANTIFYING $\Psi^{\text {tissue }}$ USING BENDING AND WATER UPTAKE ASSAYS. The sucrose concentrations, and hence the $\Psi_{\Pi}^{\text {solution }}$ values of the incubation media, had significant effects on the angles of curvature of the tissue strips (Fig. 3) and the volumes of the tissue discs as indicated by their projected surface areas (Fig. 4). High sucrose concentrations increased the angles of curvature and decreased the disc areas, whereas low concentrations decreased the angles and increased the areas. Graphs of either curvature or area vs. $\Psi_{\Pi}^{\text {solution }}$ were linear across the entire range of potentials for strips excised at 41 DAFB (Figs. 3B and 4B) and there was no discoloration of the incubation media (i.e., no cell bursting). From $\approx 55$ DAFB onward, the incubation media were discolored in the less negative $\Psi_{\Pi}^{\text {solution }}$ solutions indicating anthocyanin leakage after bursting of some cells. For these samplings, the relationships between curvature or area and $\Psi_{\Pi}^{\text {solution }}$ were approximately linear only for solutions below $\approx-1.9 \mathrm{MPa}$. Only the linear ranges were used for regression and calculation of $\Psi^{\text {tissue }}$ (Figs. 3D, 3F, 4D, and 4F). The $\Psi^{\text {tissue }}$

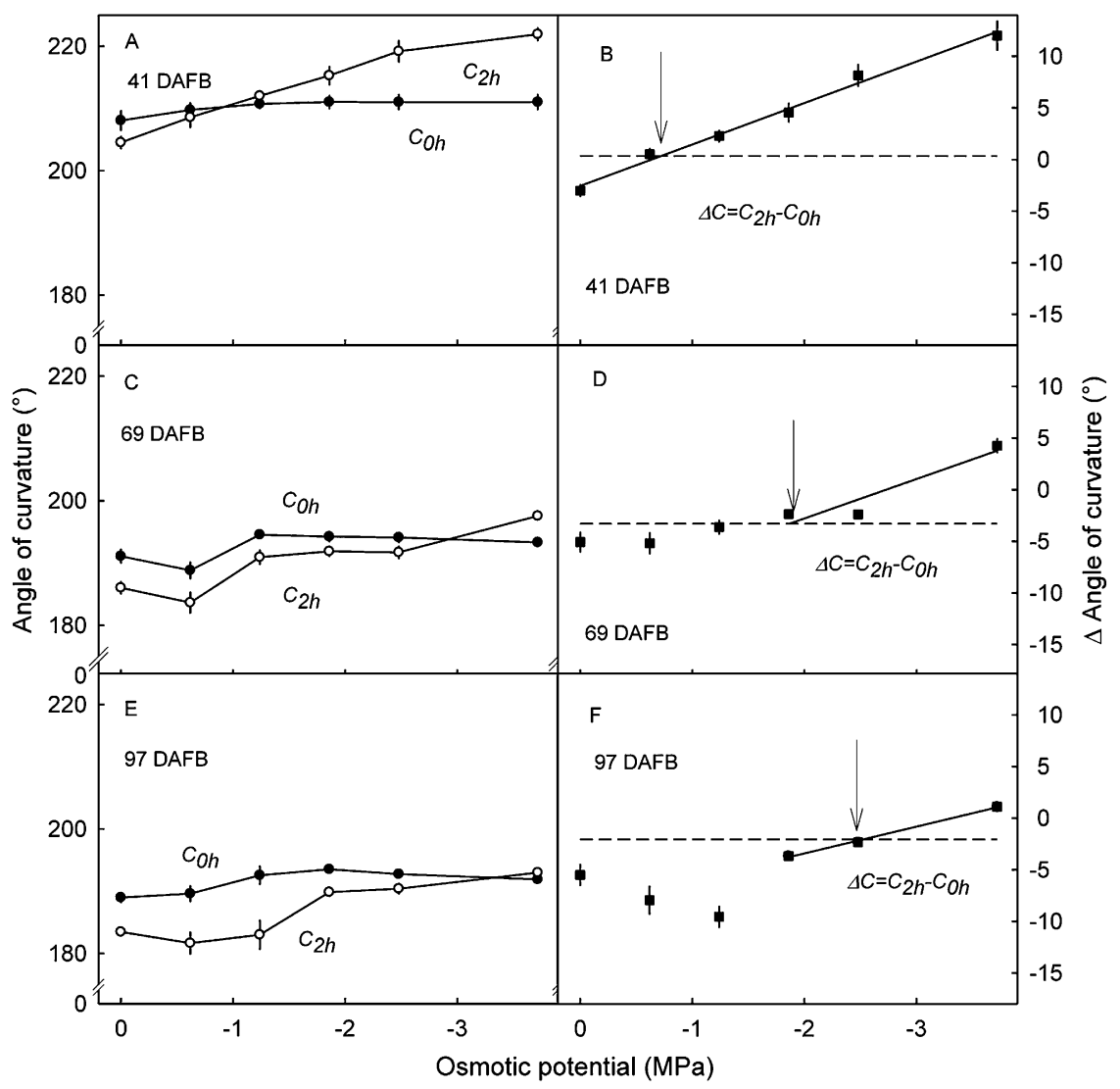

Fig. 3. Effect of the osmotic potential $\left(\Psi_{\Pi}^{\text {solution }}\right)$ of sucrose solutions on the angle of curvature of skin strips excised from the exo- and mesocarp of developing sweet cherry at 41 (A-B), 69 (C-D), and $97 \mathrm{~d}$ after full bloom [DAFB $(\mathbf{E}-\mathbf{F})]$. The angles of curvature were determined by image analysis immediately after excision and transfer of the strips into the sucrose solution $(0 \mathrm{~h})$ and after $2 \mathrm{~h}$ of incubation $[2 \mathrm{~h}(\mathbf{A}, \mathbf{C}, \mathbf{E})]$. Strips incubated in silicone oil served as a control. From these data, the change in angle of curvature ( $\Delta$ Angle) was calculated by subtracting the angles at $0 \mathrm{~h}$ from those after $2 \mathrm{~h}(\mathbf{B}, \mathbf{D}, \mathbf{F})$. The solid line and data symbols represent data for strips incubated in aqueous solutions of sucrose. The dashed line is used for the change in curvature of control strips incubated in silicone oil. For determining the tissue water potential $\left(\Psi^{\text {tissue }}\right)$, a linear regression line was fitted through a plot of the change in angle of curvature vs. $\Psi_{\Pi}^{\text {solution }}$ of the sucrose solution. The $\Psi_{\Pi}^{\text {solution }}$ at the intercept of the solid and the dashed line is indicated by the arrow and corresponds to the $\Psi^{\text {tissue }}$. values obtained from the bending and the water uptake assays were roughly constant to $\approx 48$ DAFB, but then decreased to $\approx 75$ DAFB, and again remained constant at the lower level (Fig. 5A). The $\Psi^{\text {tissue }}$ values were in good agreement with the tissue values determined by VPO.

$\Psi_{P}^{\text {fruit }}$ AND $\Psi_{P}^{\text {cell }}$ BY CP AND CPP. After a transient peak at $\approx 41$ DAFB, the values of $\Psi_{P}^{\text {fruit }}$ decreased until $\approx 63$ DAFB and then remained constant and low until maturity (Fig. 5B). There was little difference between the values of $\Psi_{P}^{\text {fruit }}$ determined by CP and those calculated from $\Psi^{\text {fruit }}$ and $\Psi_{\Pi}^{\text {fruit }}$ by VPO.

The changes in $\Psi_{P}^{\text {cell }}$ with time essentially paralleled those of $\Psi^{\text {fruit }}$. The $\Psi_{P}^{\text {cell }}$ increased from 27 to 48 DAFB, remained constant from 48 to $55 \mathrm{DAFB}$, then decreased and remained low until maturity (Fig. 5B).

\section{Discussion}

Our results establish the following: 1) the values of $\Psi_{P}^{\text {fruit }}$ and $\Psi_{P}^{c e l l}$ in sweet cherry decrease markedly at the onset of Stage III ripening from the much higher values recorded during Stage II to almost zero (i.e., atmospheric pressure) approaching maturity. This decrease coincides with the lowering of $\Psi^{\text {tissue }}$ and $\Psi_{\Pi}^{\text {fruit }}$;2) $\Psi_{P}^{\text {fruit }}$ and $\Psi_{P}^{\text {cell }}$ are always low relative to $\Psi_{\Pi}^{\text {fruit }}$ of the fruit and, therefore, $\Psi^{\text {tissue }}$ essentially equals the $\Psi_{\Pi}^{\text {fruit }}$.

DECREASES IN $\Psi_{P}^{\text {fruit }}$ AND $\Psi_{P}^{\text {cell }}$ AT The onset of Stage III. The recorded decreases in $\Psi_{P}^{\text {fruit }}$ (by CP) and $\Psi_{P}^{\text {cell }}$ (by CPP and VPO) coincide with the decreases in $\Psi_{\Pi}^{\text {fruit }}$ and the increases in fruit growth rate during early Stage III. These observations are also consistent with the transient effect of pressure on the relaxation of skin segments of cherry fruit reported earlier (Grimm et al., 2012). They further agree with the current view of the cell expansion process in which cell carbohydrate import induces a corresponding water import and an increase in cell pressure. The rise in cell pressure causes the cell wall to yield and extend, resulting in pressure decrease and so cell expansion halts. The value of $\Psi_{\Pi}^{\text {fruit }}$ of sweet cherry continues to decrease during Stage III and fruit growth rates remain high, even when $\Psi_{P}^{\text {fruit }}$ and $\Psi_{P}^{\text {cell }}$ have settled to values close to atmospheric pressure. Thus, the rapid decrease in $\Psi_{P}^{\text {fruit }}$ and $\Psi_{P}^{\text {cell }}$ observed in our study during early Stage III must have additional/different causes.

It is interesting that the different methods used for estimating $\Psi_{P}^{\text {fruit }}$ and $\Psi_{P}^{\text {cell }}$ yielded consistent decreases in both these pressures during Stage III and similar variabilities during Stage II. The value of $\Psi_{P}^{\text {fruit }}$ by CP 


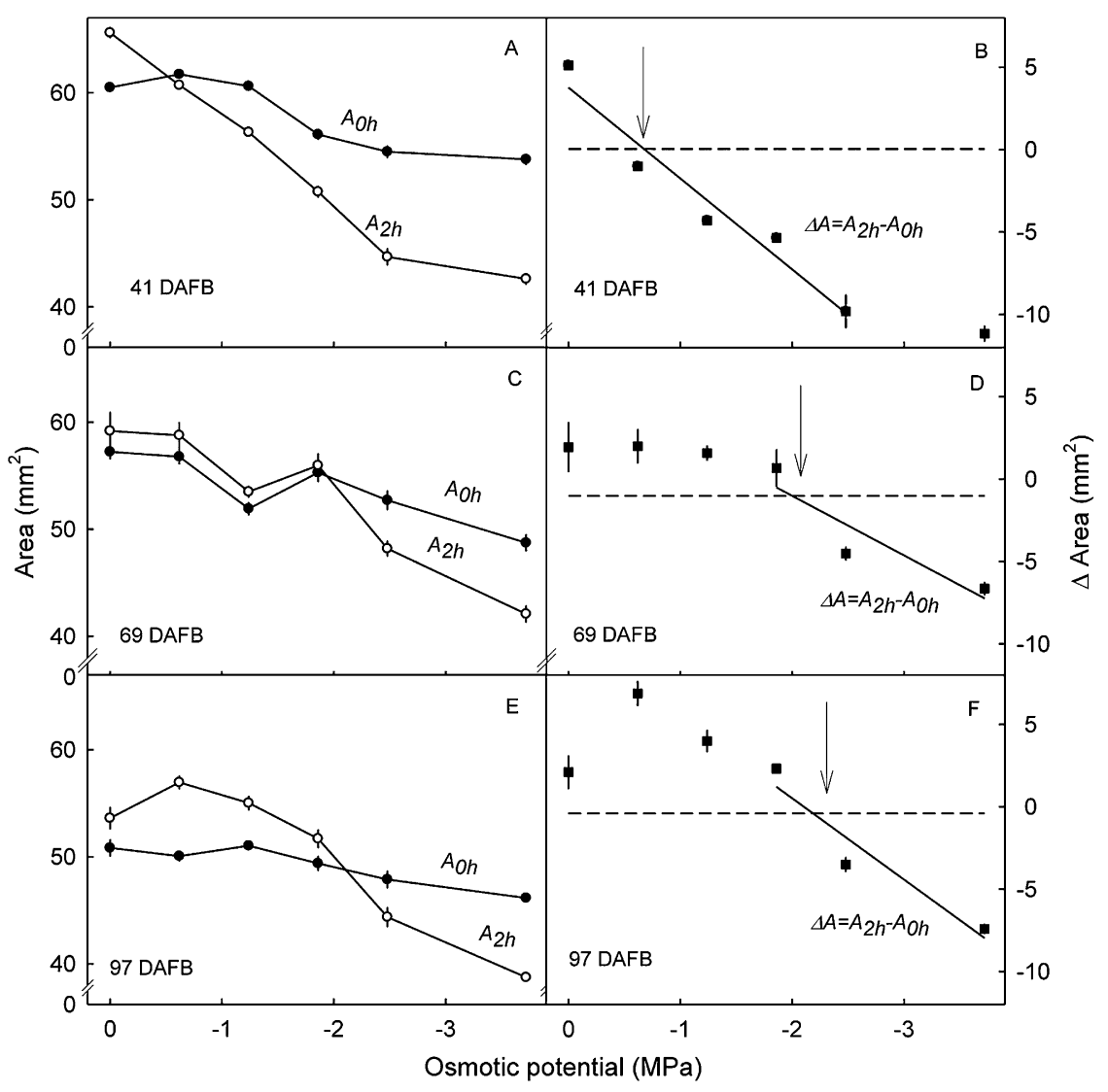

Fig. 4. Effect of the osmotic potential $\left(\Psi_{\Pi}^{\text {solution }}\right)$ of sucrose solutions on the projected surface area of tissue discs excised from the flesh of developing sweet cherry at 41 (A-B), 69 (C-D), and $97 \mathrm{~d}$ after full bloom [DAFB (EF)]. The projected surface areas were determined by image analysis immediately after excision of the discs and transfer into the sucrose solution $(0 \mathrm{~h})$ and after $2 \mathrm{~h}$ of incubation $[2 \mathrm{~h}(\mathbf{A}, \mathbf{C}, \mathbf{E})]$. Discs incubated in silicone oil served as control. From these data, the change in projected surface area ( $\Delta$ Area) was calculated by subtracting the projected areas at $0 \mathrm{~h}$ from those after $2 \mathrm{~h}(\mathbf{B}, \mathbf{D}, \mathbf{F})$. The solid line and data symbols represent data for discs incubated in aqueous solutions of sucrose. The dashed line is used for the change in area of control discs incubated in silicone oil. For determining the tissue water potential $\left(\Psi^{\text {tissue }}\right)$, a linear regression line was fitted through a plot of the change in surface area vs. $\Psi_{\Pi}^{\text {solution }}$ of the sucrose solution. The $\Psi_{\Pi}^{\text {solution }}$ at the intercept of the solid and the dashed line is indicated by the arrow and corresponds to the $\Psi^{\text {tissue }}$.

Assuming spherical geometry (a reasonable, first-order approximation for a cherry), then a $\approx 2.67$ $\mathrm{cm}$-diameter fruit will have a volume of $\approx 10 \mathrm{~mL}$. If the pit is $\approx 1.25 \mathrm{~cm}$ diameter, this will have a volume of $\approx 1 \mathrm{~mL}$, so the fleshy part of the fruit will contain $\approx 9 \mathrm{~mL}$ of juice. Assuming a skin thickness of $\approx 70 \mu \mathrm{m}$ (Glenn and Poovaiah, 1989; E. Grimm, unpublished data), then flesh and skin will account for $\approx 88 \%$ and $\approx 2 \%$ of the volume of the outer "soft" tissues, respectively (i.e., the skin cells will contribute negligibly to the expressed juice in terms of solutes). Applying similar arithmetic to the parenchyma cells of the flesh, for an average cell of $150 \mu \mathrm{m}$ diameter surrounded by a $3-\mu \mathrm{m}$-thick cell wall, the total cell volume is made up of symplast $89 \%$ and apoplast $11 \%$. Thus, the $\Psi_{\Pi}^{\text {fruit }}$ value measured by VPO is primarily a measure of the flesh symplast. Because apoplast and symplast of the flesh are likely to be in water potential equilibrium, an estimate of the $\Psi_{\Pi}^{\text {apoplast }}$ may be obtained from the $\Psi_{\Pi}^{\text {fruit }}$ and the $\Psi_{P}^{\text {cell }}$. However, because $\Psi_{P}^{\text {cell }}$ is numerically small relative to the $\Psi_{\Pi}^{\text {fruit }}$, the $\Psi_{\Pi}^{\text {apoplast }}$ and $\Psi_{\Pi}^{\text {fruit }}$ must be closely related. In fact, the coefficient of correlation between $\Psi_{\Pi}^{\text {fruit }}$ and the $\Psi_{\Pi}^{\text {apoplast }}$ estimated by subtracting $\Psi_{P}^{\text {cell }}$ from $\Psi_{\Pi}^{\text {fruit }}$ was $r=0.99^{* * *}$.

This relationship has important practical consequences. A cata-

showed a transient increase from 34 to 40 DAFB followed by a continuing decrease to maturity. The peak in $\Psi_{P}^{\text {fruit }}$ during Stage II could be an artefact at the beginning of pit hardening that may have increased the resistance to deformation and caused an overestimation of $\Psi_{P}^{\text {fruit }}$. Because pit hardening continues, the transient nature of this increase must be accounted for by a net effect of pit hardening (causing the increase in $\Psi_{P}^{\text {fruit }}$ ), and the increase in fruit mass and possibly the beginning of fruit softening (causing the decrease in $\Psi_{P}^{\text {fruit }}$ ) (Kondo and Danjo, 2001).

The discrepancy between the $\Psi_{P}^{\text {cell }}$ calculated from VPO measurements and that by CPP between 27 and 48 DAFB is more difficult to explain. At $34 \mathrm{DAFB}$, fruit were too small to prepare tissue discs for VPO that consisted of flesh only. Thus, in these young fruit, a mixture of tissues was involved in VPO yielding an averaged value for $\Psi_{P}^{\text {cell }}$. In contrast, the CPP quantified the $\Psi_{P}^{\text {cell }}$ of cells of the outer flesh only.

$\Psi_{P}^{\text {fruit }}$ AND $\Psi_{P}^{\text {cell }}$ ARE NUMERICALLY LOW RELATIVE TO $\Psi_{\Pi}^{\text {fruit }}$. The $\Psi_{\Pi}^{\text {fruit }}$ of expressed juice predominantly reflects the content of the symplast of the flesh cells. Based on the following calculations, the contributions made by the skin cells (apoplast plus symplast) and that of the flesh apoplast will be small. strophic increase in $\Psi_{P}^{\text {cell }}$ that would result from the rapid and continuing decrease (more negative) in $\Psi_{\Pi}^{\text {fruit }}$ during Stage III development is prevented by the concurrent decrease in $\Psi_{\Pi}^{\text {apoplast }}$. This conclusion is consistent with earlier findings in sweet cherry (Knoche et al., 2014) and grape (Matthews and Shackel, 2005; Wada et al., 2008, 2009). In grape, carbohydrates accumulate in the apoplast causing $\Psi_{P}^{\text {cell }}$ to decrease rapidly from preveraison to postveraison (Wada et al., 2008, 2009). At present there is no such evidence for sweet cherry.

If solute accumulation in the cell wall space balanced the decrease in $\Psi_{\Pi}^{\text {fruit }}$ of the symplast, the question arises how the developing cherry synchronizes the simultaneous decrease in $\Psi_{\Pi}^{a p o p l a s t}$. In principle, three different mechanisms may be thought of that would account for the presence of apoplastic solutes. First, a collapse and leakage of cell contents into the apoplast may occur because of cracking of individual cells. Based on these volume ratios estimated for symplast and apoplast, a fraction of $\approx 10 \%$ of the cells of the flesh would have a volume equivalent to that of the flesh apoplast. If these cracked, their content would leak into the apoplast causing $\Psi_{\Pi}^{a p o p l a s t}$ to decrease. Interestingly, Lang and Düring (1991) reported a breakdown of compartmentation in postveraison 


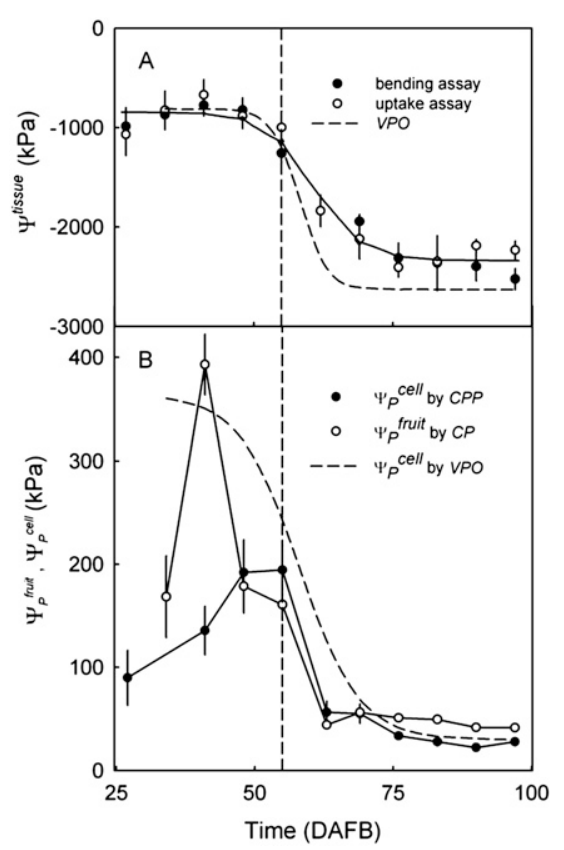

Fig. 5. (A) Change in tissue water potential ( $\Psi^{\text {tissue }}$ ) of skin strips (bending assay) or flesh discs (water uptake assay) excised from developing 'Regina' sweet cherry. In the bending assay, skin strips comprising exocarp and mesocarp were incubated in sucrose solutions of differing osmotic potential $\left(\Psi_{\Pi}^{\text {solution }}\right)$ and the change in angle of curvature monitored (Fig. 3). In the water uptake assay, flesh discs were incubated in a series of sucrose solution of differing $\Psi_{\Pi}^{\text {solution }}$ and the change in surface area of the discs monitored. The $\Psi_{\Pi}^{\text {solution }}$ of the sucrose solution where there was no change in bending or water uptake as compared with a control that was incubated in silicone oil corresponded to the $\Psi^{\text {tissue }}$. The sigmoid dashed regression line was redrawn from Figure $2 \mathrm{~A}$ and represents the $\Psi^{\text {tissue }}$ as determined by water vapor pressure osmometry (VPO). (B) Changes in pressure of the fruit $\left(\Psi_{P}^{\text {fruit }}\right)$ and in pressure of cells of the outer flesh $\left(\Psi_{P}^{\text {cell }}\right)$ of developing sweet cherry. $\Psi_{P}^{\text {fruit }}$ and $\Psi_{P}^{\text {cell }}$ were determined using the compression plate test $(\mathrm{CP})$ and the cell pressure probe (CPP). The sigmoid dashed regression line represents the $\Psi_{P}^{\text {cell }}$ as determined by VPO and was redrawn from Figure 2B. The vertical dashed line indicates transition from Stage II to Stage III at $\approx 55 \mathrm{~d}$ after full bloom (DAFB).

grape that resulted in a flooding of the berries' apoplast with carbohydrates. Also, Tilbrook and Tyerman (2008) reported programmed cell death and loss of osmotic competent membranes in some grape berry varieties, which explain the presence of solutes in the apoplast. If this was a factor, we would expect cellular carbohydrates and vacuolar anthocyanins to be present in the apoplast. Second, apoplastic solutes may arise from a mismatch of unloading of the phloem into the apoplast and the subsequent uptake from the apoplast into the symplast of the flesh. If the rate of unloading exceeded the rate of uptake, solutes would accumulate in the apoplast. Third, solutes may also accumulate as products from the enzymatic degradation of cell wall constituents that begins in sweet cherry as early as 30 DAFB (Kondo and Danjo, 2001). Further research is needed to clarify this issue.

Although the general observation of decreasing $\Psi_{P}^{\text {fruit }}, \Psi_{P}^{\text {cell }}$, $\Psi^{\text {tissue }}$, and $\Psi_{\Pi}^{\text {fruit }}$ during Stage III was consistent for all pressures and potentials determined using a range of methods, some differences were noted. For example, the transient peak in $\Psi_{P}^{\text {fruit }}$ at 41 DAFB recorded by CP was not paralleled by the $\Psi_{P}^{c e l l}$ as determined by VPO or CPP. The reason for this discrepancy is unknown but may be related to the firm texture and the hardening pit of late Stage II fruit. This fruit will offer significant resistance to deformation and here, the model of a stretched skin holding the interior flesh of the fruit under compression may not be entirely applicable. Consequently, the $\Psi_{P}^{\text {frut }}$ would be overestimated. Also, earlier studies from our laboratory demonstrate that there is essentially no strain of the skin during Stage II and, accordingly, no reason for significant $\Psi_{P}^{\text {fruit }}$ to develop (Grimm et al., 2012).

That the estimates of $\Psi^{\text {tissue }}$ obtained in the bending assay and the uptake assay were essentially identical is not surprising. Both assays rely on water uptake driven by the gradient in water potential between the donor/recipient solution and the tissue. The estimates of $\Psi^{\text {tissue }}$ are in good agreement with the $\Psi_{\Pi}^{\text {fruit }}$ by VPO, the $\Psi^{\text {tissue }}$ by VPO, and the absence of significant $\Psi_{P}^{\text {fruit }}$ and $\Psi_{P}^{\text {cell }}$.

\section{Conclusions}

The decrease in $\Psi_{P}^{\text {fruit }}$ and $\Psi_{P}^{\text {cell }}$ during early Stage III and their low values relative to the continuously decreasing $\Psi_{\Pi}^{\text {fruit }}$ can only be accounted for by the simultaneous accumulation of solutes in the cherry's apoplast. From a practical point of view, this process is essential in avoiding a catastrophic increase in pressure leading to the bursting of individual cells and the cracking of entire fruit. A going consequence, however, is that the water potential of the fruit decreases as well, causing the driving force for water uptake through the skin during precipitation to increase. Furthermore, from these findings, it is clearly evident that the hypothesis that cracking is caused by increased tissue pressure must be rejected.

\section{Literature Cited}

Bernstein, Z. and I. Lustig. 1981. A new method of firmness measurement of grape berries and other juice fruits. Vitis 20:15-21. Bernstein, Z. and I. Lustig. 1985. Hydrostatic methods of measurement of firmness and turgor pressure of grape berries (Vitis vinifera L.). Sci. Hort. 25:129-136.

Christensen, J.V. 1996. Rain-induced cracking of sweet cherries. Its causes and prevention, p. 297-327. In: Webster, A.D. and N.E. Looney (eds.). Cherries. CAB Intl., Wallingford, UK.

Considine, J.A. and P.E. Kriedemann. 1972. Fruit splitting in grapes. Determination of the critical turgor pressure. Aust. J. Agr. Res. 23:17-24.

Glenn, G.M. and B.W. Poovaiah. 1989. Cuticular properties and postharvest calcium applications influence cracking of sweet cherries. J. Amer. Soc. Hort. Sci. 114:781-788.

Grimm, E., S. Peschel, T. Becker, and M. Knoche. 2012. Stress and strain in the sweet cherry fruit skin. J. Amer. Soc. Hort. Sci. 137:383390 .

Knoche, M., M. Beyer, S. Peschel, B. Oparlakov, and M.J. Bukovac. 2004. Changes in strain and deposition of cuticle in developing sweet cherry fruit. Physiol. Plant. 120:667-677.

Knoche, M., E. Grimm, and H. Schlegel. 2014. Mature sweet cherries have low turgor. J. Amer. Soc. Hort. Sci. 139:3-12.

Kondo, S. and C. Danjo. 2001. Cell wall polysaccharide metabolism during fruit development in sweet cherry 'Satohnishiki' as affected by gibberellic acid. J. Jpn. Soc. Hort. Sci. 70:178-184.

Lang, A. and H. Düring. 1991. Partitioning control by water potential gradient: Evidence for compartmentation breakdown in grape berries. J. Expt. Bot. 42:1117-1122.

Lilleland, O. and L. Newsome. 1934. A growth study of the cherry fruit. Proc. Amer. Soc. Hort. Sci. 32:291-299.

Matthews, M.A. and K.A. Shackel. 2005. Growth and water transport in fleshy fruit, p. 181-197. In: Holbrook, N.M. and M.A. Zwieniecki 
(eds.). Vascular transport in plants. Elsevier Academic Press, Amsterdam, The Netherlands.

McGuire, R.G. 1992. Reporting of objective color measurements. HortScience 27:1254-1255.

Measham, P.F., S.A. Bound, A.J. Gracie, and S.J. Wilson. 2009. Incidence and type of cracking in sweet cherry (Prunus avium L.) are affected by genotype and season. Crop Pasture Sci. 60:10021008.

Sekse, L. 1995. Fruit cracking in sweet cherries (Prunus avium L.). Some physiological aspects-A mini review. Sci. Hort. 63:135-141.

Sekse, L., K.L. Bjerke, and E. Vangdal. 2005. Fruit cracking in sweet cherries - An integrated approach. Acta Hort. 667:471-474.

Steudle, E. 1993. Pressure probe techniques: Basic principles and application to studies of water and solute relations at the cell, tissue and organ level, p. 5-36. In: Smith, J.A.C. and H. Griffiths (eds.). Water deficits: Plant responses from cell to community. Bios Scientific Publishers, Oxford, UK.
Tilbrook, J. and S.D. Tyerman. 2008. Cell death in grape berries: Varietal differences linked to xylem pressure and berry weight loss. Funct. Plant Biol. 35:173-184.

Tukey, H.B. 1934. Growth of the embryo, seed, and pericarp of the sour cherry (Prunus cerasus) in relation to season of fruit ripening. Proc. Amer. Soc. Hort. Sci. 31:125-144.

Tyerman, S.D., J. Tilbrook, C. Pardo, L. Kotula, W. Sullivan, and E. Steudle. 2004. Direct measurement of hydraulic properties in developing berries of Vitis vinifera L. cv. Shiraz and Chardonnay. Austral. J. Grape Wine Res. 10:170-181.

Wada, H., M.A. Matthews, and K.A. Shackel. 2009. Seasonal pattern of apoplastic solute accumulation and loss of cell turgor during ripening of Vitis vinifera fruit under field conditions. J. Expt. Bot. 60:1773-1781.

Wada, H., K.A. Shackel, and M.A. Matthews. 2008. Fruit ripening in Vitis vinifera: Apoplastic solute accumulation accounts for preveraison turgor loss in berries. Planta 227:1351-1361. 